\title{
Application of Electrocoagulation for the Removal of Color from Institutional Wastewater: Analysis with Response Surface Methodology
}

\author{
Million Ebba* \\ Department of Water Supply and Environmental Engineering, Faculty of Civil and Environmental Engineering, Institute of Technology, Jimma \\ University, Oromia, Ethiopia
}

Received: 16/09/2020

Accepted: 25/01/2021

Published: 20/06/2021

\begin{abstract}
The removal percentage of color from institutional wastewater was studied using an electrocoagulation process with different electrode combination at the anode and cathode. This was done by considering operational parameters such as $\mathrm{pH}$ at $(3,6$ and 9$)$, current at $(0.03 \mathrm{~A}, 0.06 \mathrm{~A}$ and $0.09 \mathrm{~A})$ and reaction time at $(20,40$ and 60 minutes). When electrode combined in the form of $\mathrm{Al}-\mathrm{Al}$ (anode-Cathode/Cathode-Anode) and Fe-Fe (anode-Cathode/Cathode-Anode) the percentage removal of color was up to $95.50 \%$ and $97.24 \%$ respectively. On the other hand around $98.03 \%$ and $91.95 \%$ of color was removed when Al-Fe (Anode-Cathode) and Fe-Al (Anode-Cathode) combined at $\mathrm{pH} 9$ and 60 minutes of reaction time respectively. Central composite design from response surface methodology was used up to analysis the statistical and mathematical data based on experimental results such as the model was significant for all electrode combinations. Similarly a quadratic model was used for further study of operational effects on the removal $(\%)$ of color from institutional wastewater. The value of coefficient of the determination $\left(\mathrm{R}^{2}\right)$ also indicated the model was a good fit as well as optimization was done by Response Surface Methodology.
\end{abstract}

Keywords: Color, Electrocoagulation, Electrode, Institutional wastewater, RSM

\section{Introduction}

Water is a natural resource that is important for human beings and other creatures to survive on the earth (1-3). However, water scarcity was happening in the world, especially in developing countries due to over population (4-7), urbanization $(5,8,9)$, industrialization $(5,7-9)$, deforestation (5), Agriculture $(7,9,10)$, global climate change that cause global warming $(4,5)$ and also those problems and others cause the formation of wastewater.

Wastewater generated from different sources such as domestic (11-13), commercial (14), institution (15), agriculture (16), industrial $(11,17)$ and etc. that contains different pollutants. Depending on the volume and quantity of wastewater and also the concentration of pollutants in wastewater, receiving environments can affect when directly emitted to an environment without any treatment which indirectly puts the life of animal and human in danger (18). Different researchers indicated there are different metho ds of water and wastewater treatment like; photo catalytic deg radation (19-21), adsorption $\quad(2,11,19,22,23)$, Ion exchange (11), chemical precipitation $(11,23)$, reverse osmosis $(11,22)$, ultrafiltration $(11,24)$, electrocoagulation $(22,23,25$

28 ), sedimentation (27), Nano filtration (22,29), filtration (30, 31 ), electro-flotation $(23,32)$ and etc. Electrocoagulation is a recent technology used for the treatment of water and wastewater by applying electric current to sacrificial electrodes based on the dissolving of cationic metallic species through an electrochemical process (33). It is the combination of electro which means applying an electrical charge to a water and coagulation which means the way of minimizing the colloidal particle surface charge that resulted suspended matter for the formation agglomeration with various electrodes like aluminum, iron, graphite and stainless steel (25). Electrocoagulation is preferable for water and wastewater treatment due to different reasons such as simple for installation $(18,34,35)$, no chemical used up during the process $(18,34-36)$, electron is the only reagent (18), shortest treatment time $(18,32,34,35)$, highest removal efficiency $(18,32,36-38)$, produce less sludge $(18,35,36,38,39)$, reliable and cost $(35,37,39,40)$. In most water and wastewater treatment Aluminum and Iron electrodes are used for electrocoagulation process and there are different chemical reactions taking place at the anode and the cathode which are shown in the equation shown below (41). At Anode reaction for Aluminum:

$\mathrm{Al}_{(\mathrm{s})} \rightarrow \mathrm{Al}^{3+}+3 \mathrm{e}^{-}$

At Cathode reaction for Aluminum

$3 \mathrm{H}_{2} \mathrm{O}+3 \mathrm{e}^{-} \rightarrow\left(\frac{3}{2}\right) \mathrm{H}_{2}+3 \mathrm{OH}^{-}$

Overall reaction

Corresponding author: Million Ebba, Department of Water Supply and Environmental Engineering, Faculty of civil and Environmental Engineering, Jimma University, Institute of technology. E-mail: millionebba@gmail.com 
$\mathrm{Al}_{(\mathrm{aq})}^{3+}+3 \mathrm{H}_{2} \mathrm{O} \rightarrow \mathrm{Al}(\mathrm{OH})_{3} \downarrow_{(\mathrm{s})}+3 \mathrm{H}^{+}$

The cationic monomeric species like $\mathrm{Al}^{3+}$ and $\mathrm{Al}(\mathrm{OH})_{2}^{+}$ are produced due to the electrical dissolution of Aluminum at Anode at low $\mathrm{pH}$ such that the values are transferred to $\mathrm{Al}(\mathrm{OH})_{3}$ at appropriate $\mathrm{pH}$ and finally polymerized to $\mathrm{AL}_{\mathrm{n}}(\mathrm{OH})_{3 \mathrm{n}}$ that shown in Eq.(4) (41).

$\mathrm{nAL}(\mathrm{OH})_{3} \downarrow_{(\mathrm{s})} \rightarrow \mathrm{Al}_{\mathrm{n}}(\mathrm{OH})_{3 \mathrm{n}} \downarrow_{(\mathrm{s})}$

On the other hand, there are two mechanisms for the production of $\mathrm{Fe}(\mathrm{OH})_{\mathrm{n}}$, either $\mathrm{n}$ is 2 or 3 based on the oxidation of Iron electrode that indicated below $(41,42)$.

\section{Mechanism 1}

At Anode Reaction

$$
\begin{aligned}
& 4 \mathrm{Fe}_{(\mathrm{s})} \rightarrow 4 \mathrm{Fe}_{(\mathrm{aq})}^{2+}+8 \mathrm{e}^{-} \\
& 4 \mathrm{Fe}_{(\mathrm{aq})}^{2+}+10 \mathrm{H}_{2} \mathrm{O}+\mathrm{O}_{2(\mathrm{~g})} \rightarrow 4 \mathrm{Fe}(\mathrm{OH})_{3(\mathrm{~g})}+8 \mathrm{H}_{(\mathrm{aq})}^{+}
\end{aligned}
$$

\section{At Cathode Reaction}

$8 \mathrm{H}_{(\mathrm{aq})}^{+}+8 \mathrm{e}^{-} \rightarrow 4 \mathrm{H}_{2(\mathrm{~g})}$

Overall reaction

$4 \mathrm{Fe}_{(\mathrm{s})}+10 \mathrm{H}_{2} \mathrm{O}_{(\mathrm{l})}+\mathrm{O}_{2(\mathrm{~g})} \rightarrow 4 \mathrm{Fe}(\mathrm{OH})_{3(\mathrm{~g})}+4 \mathrm{H}_{2(\mathrm{~g})}$

\section{Mechanism 2}

At Anode Reaction

$$
\begin{aligned}
& \mathrm{Fe}_{(\mathrm{s})} \rightarrow \mathrm{Fe}_{(\mathrm{aq})}^{2+}+2 \mathrm{e}^{-} \\
& \mathrm{Fe}_{(\mathrm{aq})}^{2+}+2 \mathrm{OH}^{-} \rightarrow \mathrm{Fe}(\mathrm{OH})_{2(\mathrm{~s})}
\end{aligned}
$$

\section{At Cathode Reaction}

$2 \mathrm{H}_{2} \mathrm{O}+2 \mathrm{e}^{-} \rightarrow \mathrm{H}_{2}+2 \mathrm{OH}^{-}$

Overall Reaction

$$
\mathrm{Fe}_{(\mathrm{s})}+2 \mathrm{H}_{2} \mathrm{O}_{(\mathrm{l})} \rightarrow \mathrm{Fe}(\mathrm{OH})_{2(\mathrm{~s})}+\mathrm{H}_{2(\mathrm{~g})}
$$

Recent studies are indicating electrocoagulation technology was used in different wastewater treatment area such as Health institution $(15,43)$, slaughter house $(24,44,45)$, automobile service stations (25) and etc. After experimental investigation, optimizations of analytical processes are done by applying multivariate statistical techniques called Response Surface methodology (RSM) (15). The main objective of Response surface methodology was to determine the optimum conditions of different variables to predict the targeted responses (46). It works based on the input or independent variables and the output or responses after the design of experiments; RSM was applied according to the central composite design to determine optimum conditions of variables (46).

In this study the removal percentage of wastewater Color was evaluated that generated from the Jimma University Institute of technology by using electrocoagulation under the operational parameters such as $\mathrm{pH}$, current and reaction time. This was done for $\mathrm{Al}-\mathrm{Al}, \mathrm{Fe}-\mathrm{Fe}, \mathrm{Al}-\mathrm{Fe}$ and $\mathrm{Fe}-\mathrm{Al}$ and also the statistical and mathematical analysis was evaluated with Response Surface Methodology.

\section{Materials and methods \\ 2.1 Materials}

The sample was collected from Wastewater generated from the Jimma University Institute of technology and experimental investigation was conducted at the Jimma University Institute of technology, Environmental engineering Laboratory. So during Color removal percentage evaluation, different materials were used such as DC power supply, Electrocoagulation cell, electrodes (Aluminum and Iron), magnetic stirrer, magnetic bar stirrer, electrical clips, copper wires and spectrophotometer.

\subsection{Experimental setup of electrocoagulation}

An electrocoagulation experiment conducted was a batch mode where a removal percentage was evaluated at different time intervals. As shown in Fig. 1, an experimental setup of electrocoagulation was performed where two parallel electrodes either Aluminum or Iron was immersed into a batch beaker of 1.5L holding capacity. The electrodes are connected in the form of $\mathrm{Al}-\mathrm{Al}$ (Anode-Cathode/Cathode-Anode), $\mathrm{Fe}-\mathrm{Fe}$ (Anode-Cathode/Cathode-Anode), Al-Fe (Anode-Cathode) and $\mathrm{Fe}-\mathrm{Al}$ (Anode-Cathode) that connected to a DC power supply by using copper wires before immersed into a batch beaker. Since $\mathrm{pH}$ was one operational parameter considered in this study, sodium hydroxide or sulfuric acid was used to adjust the $\mathrm{pH}$ of the wastewater sample. The surface area of both electrodes was the same and after each experimental run, electrodes are cleaned by hydrochloric acid and followed by distilled water. Magnetic stirrer bar was placed inside an electrocoagulation cell in order to obtain a uniform concentration of a sample. A power supply was turned on for DC power and magnetic stirrer after all operational parameters are adjusted.

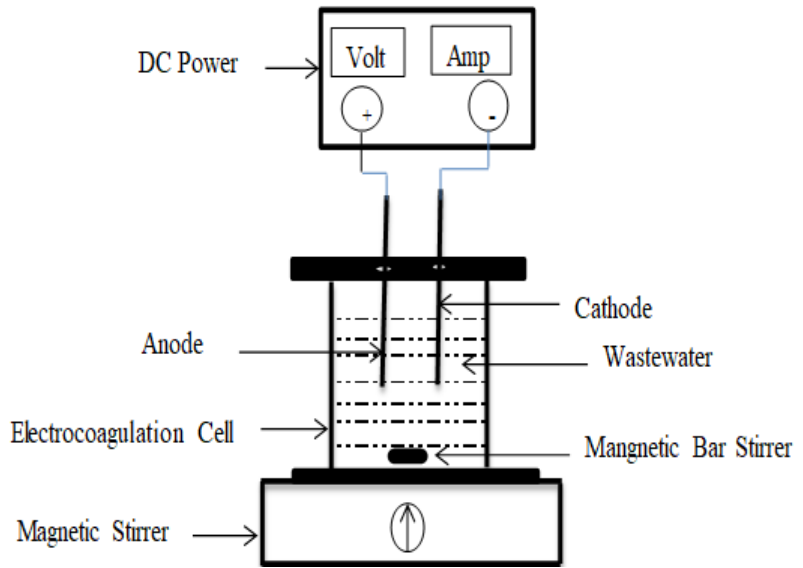

Figure 1: Schematic setup of electrocoagulation

\subsection{Experimental Design with RSM}

Experimental parameter for color removal was studied for by using the electrocoagulation process for the treatment of institutional wastewater (i.e. on the wastewater generated from the Jimma University Institute of Technology). The mathematical and statistical analysis was done by Central Composite design (CCD) for three operating parameters. Design of Expert software (Version 11) was used for optimization and effect of those variables on the removal percentage of color. All variables are coded from -1 to +1 such that $\mathrm{pH}\left(\mathrm{X}_{1}\right)$, Current $\left(\mathrm{X}_{2}\right)$ and Reaction time $\left(\mathrm{X}_{3}\right)$ that ranges 
from 3 - 9, $0.03-0.09 \mathrm{~A}$ and $20-60$ minutes respectively. The levels and variables of an experimental design were shown in Table 1. Based on the Central Composite Design for three variables, eighteen experiments were performed, including replications from center points.

Table 1: Experimental Design for variables with CCD

\begin{tabular}{llllll}
\hline Variables & Units & Factors & \multicolumn{3}{c}{ Levels } \\
\hline & & & -1 & 0 & +1 \\
$\mathrm{pH}$ & & $\mathrm{X}_{1}$ & 3 & 6 & 9 \\
Current & Ampere (A) & $\mathrm{X}_{2}$ & 0.03 & 0.06 & 0.09 \\
$\begin{array}{l}\text { Reaction } \\
\text { Time }\end{array}$ & minutes & $\mathrm{X}_{3}$ & 20 & 40 & 60 \\
\hline
\end{tabular}

\subsection{Analysis}

Based on experimental results spectrophotometer was used to determine the absorbance of institutional wastewater treatment that empirically calculated using Eq. (13) shown below $(23,26,34)$ and also based on the response surface methodology was used up for analyzing and evaluating statistical and mathematical based on experimental data as an input.

Percentage removal of Color $=\frac{\mathrm{Abs}_{\mathrm{i}}-\mathrm{Abs}_{\mathrm{f}}}{\mathrm{Abs}_{\mathrm{i}}} * 100$

where, $\mathrm{Abs}_{\mathrm{i}}$ and $\mathrm{Abs}_{\mathrm{f}}$ are initial and final absorbance of a solution respectively.

\section{Results and discussion \\ 3.1 Decolorization of Wastewater \\ 3.1.1 Decolorization using Al-Al Combination}

During experimental investigation Aluminum electrode is combined in the form of $\mathrm{Al}-\mathrm{Al}$ (Anode-Cathode/CathodeAnode) to evaluate the removal percentage of color on institutional wastewater which shown in Table 2. When the $\mathrm{pH}$ is 3 and current is $0.03 \mathrm{~A}$ and also when the $\mathrm{pH}$ is 6 and current is $0.06 \mathrm{~A}$, color removed up to $61.54 \%$ and $69.5 \%$ at the reaction time of 60 minutes respectively. The maximum removal efficiency of color was observed when the $\mathrm{pH}$ is 9 and current is $0.09 \mathrm{~A}$ at the reaction time of 60 minutes that is $95.50 \%$. On the other hand, keeping the $\mathrm{pH}$ to 3 and increasing the electric current to $0.006 \mathrm{~A}$, Decolorization of an effluent was relatively increased.

Similarly, the removal percentage of color from an effluent was $42.25,57.10$ and $74.34 \%$ when the $\mathrm{pH}$ is 6 and current is $0.09 \mathrm{~A}$ at the reaction time of 20,40 and 60 minutes respectively. When the $\mathrm{pH}$ is 9 and electric current is $0.03 \mathrm{~A}$, Decolorization of an effluent was up to $65 \%$ at the reaction time of 60 minutes. So using Al-Al (Anode-Cathode/CathodeAnode) is somewhat a good combination to remove a color from wastewater.

\subsubsection{Decolonization using Fe-Fe Combination}

When an electrode is combined in the form of Fe-Fe (AnodeCathode/Cathode-Anode) different percentage of color removal was registered at different $\mathrm{pH}$, current and reaction time that shown in Table 2. When the $\mathrm{pH}$ is 3 and current is $0.03 \mathrm{~A}$ as well as when the $\mathrm{pH}$ is 6 and current is $0.06 \mathrm{~A}$, the removal percentage of an effluent was up to 78.87 and $81.88 \%$ in 60 minutes respectively. Similarly, when the $\mathrm{pH}$ is 3 and current $0.06 \mathrm{~A}$ and also when the $\mathrm{pH}$ is 9 and current is $0.09 \mathrm{~A}$, Decolorization was increased with the reaction time such that 81.80 and $87.52 \%$ respectively. Using this electrode combination around $97.24 \%$ of color was removed from wastewater when the $\mathrm{pH}$ is 9 and $0.09 \mathrm{~A}$. On the other hand around $38.47,59.90$ and $75.86 \%$ of color was removed from an effluent when the $\mathrm{pH}$ of a wastewater is adjusted to 9 and electric current is $0.03 \mathrm{~A}$ at 20,40 and 60 minutes respectively. Hence, depending on the results this combination is an effective for Decolorization especially at high $\mathrm{pH}$, current and reaction time.

\subsubsection{Decolorization using Al-Fe Combination}

This is another combination that considered evaluating the removal percentage of color from institutional wastewater. At different $\mathrm{pH}$ values and current the removal percentage of color from an effluent was varied at different reaction time. Based on this when the $\mathrm{pH}$ is 3 and the current is $0.03 \mathrm{~A}$ and $0.06 \mathrm{~A}$, Decolorization of an effluent were $48.48,61.21,73.94 \%$ and $52.08,67$ and $78.54 \%$ at the reaction time of 20, 40 and 60 minutes respectively which shown in Table 2 . When the $\mathrm{pH}$ was increased to 6 and the current was $0.06 \mathrm{~A}$ and $0.09 \mathrm{~A}$, the removal percentage of color was up to $89.33 \%$ and $92.40 \%$ at the reaction time of 60 minutes respectively. But the maximum removal efficiency was registered when the $\mathrm{pH}$ is 9 and an electric current was $0.09 \mathrm{~A}$ at the reaction time of 60 minutes. At this level around $98.03 \%$ of color was removed from an effluent. Similarly, around $50.70 \%, 64.67 \%$ and $79.23 \%$ of color was removed just keeping the $\mathrm{pH}$ to 9 and reducing the current to $0.09 \mathrm{~A}$ at the reaction time of 20,40 and 60 minutes respectively. Hence this indicates that $\mathrm{Al}-\mathrm{Fe}$ (Anode-Cathode) combination is an effective way to remove color from an effluent.

\subsubsection{Decolorization using Fe-Al Combination}

When Fe-Al (anode-Cathode) was combined the removal efficiency of color was evaluated with the operating parameters, such as $\mathrm{pH}$, current and reaction time that shown in Table 2. Keeping the $\mathrm{pH}$ to 3 and when an electric current was $0.03 \mathrm{~A}$ and $0.06 \mathrm{~A}$, Decolorization was up to $42.86 \%$ and $55 \%$ at the reaction time of one hour respectively. This indicates the removal percentage was increased by increasing the current. On the other hand, when the $\mathrm{pH}$ is 6 and varying the current to $0.06 \mathrm{~A}$ and $0.09 \mathrm{~A}, 48.29 \%, 65 \%, 83.57 \%$ and $54.32 \%, 70.45 \%$ and $88.64 \%$ color was removed respectively at the reaction time of 20, 40 and 60 minutes. Around $91.95 \%$ was removed when the $\mathrm{pH}$ was 9 and an electric current was $0.09 \mathrm{~A}$ and also keeping the $\mathrm{pH}$ to 9 and by reducing an electric current to $0.03 \mathrm{~A}$, Decolorization of an effluent was $25.88 \%, 31.50 \%$ and $52.12 \%$ at the reaction time of 20,40 and 60 minutes respectively.

Generally, when $\mathrm{pH}$ was 3 and current was $0.03 \mathrm{~A}, \mathrm{Al}-\mathrm{Fe}$ (Anode-Cathode) was at best on the removal of color especially on the 20 and 40 minutes of reaction time. However, at 60 minutes of reaction time $\mathrm{Fe}-\mathrm{Fe}$ (Anode-Cathode/CathodeAnode) was a good combination that removed up to $78.87 \%$. Similarly, when the $\mathrm{pH}$ was 6 and 9 and also current was $0.06 \mathrm{~A}$ and $0.09 \mathrm{~A}, \mathrm{Al}-\mathrm{Fe}$ (Anode-Cathode) was the best combination to others on the removal percentage. When the $\mathrm{pH}$ was 3 and 6 as well as also the current was $0.06 \mathrm{~A}$ and $0.09 \mathrm{~A}, \mathrm{Fe}-\mathrm{Fe}$ and $\mathrm{Al}-$ $\mathrm{Fe}$ combinations are relatively the best relative to another. Again, when $\mathrm{pH} 9$ and an electric current was $0.03 \mathrm{~A}, \mathrm{Al}-\mathrm{Fe}$ was an effective compared to others.

\subsection{Design of expert Software for the evaluation of experimental results}

The removal percentage of color was determined based on the operating parameters such as $\mathrm{pH}\left(\mathrm{X}_{1}\right)$, Current $\left(\mathrm{X}_{2}\right)$ and Reaction time $\left(\mathrm{X}_{3}\right)$. Design of expert was used and the quadratic regression equation obtained from $\mathrm{Al}-\mathrm{Al}, \mathrm{Fe}-\mathrm{Fe}, \mathrm{Al}-$ $\mathrm{Fe}$ and $\mathrm{Fe}-\mathrm{Al}$ that is given in Eq. (14-17) respectively. 
Color Removal $(\%)=+50.20+8.93 \mathrm{X}_{1}+9.38 \mathrm{X}_{2}+$ $17.94 \mathrm{X}_{3}+7.74 \mathrm{X}_{1} \mathrm{X}_{2}-0.2403 \mathrm{X}_{1} \mathrm{X}_{3}-1.61 \mathrm{X}_{2} \mathrm{X}_{3}+$ 3.103.10X $\mathrm{X}_{1}^{2}-3.82 \mathrm{X}_{2}^{2}+3.20 \mathrm{X}_{3}^{2}$

Color Removal $(\%)=+61.94+3.18 \mathrm{X}_{1}+3.99 \mathrm{X}_{2}+$ $12.64 \mathrm{X}_{3}+2.43 \mathrm{X}_{1} \mathrm{X}_{2}-0.7187 \mathrm{X}_{1} \mathrm{X}_{3}+2.20 \mathrm{X}_{2} \mathrm{X}_{3}+$ $0.3906 X_{1}^{2}-0.1594 X_{2}^{2}-1.28 X_{3}^{2}$

Color Removal $(\%)=+78.53+5.77 \mathrm{X}_{1}+5.83 \mathrm{X}_{2}+$ $13.50 \mathrm{X}_{3}+3.94 \mathrm{X}_{1} \mathrm{X}_{2}+0.6150 \mathrm{X}_{1} \mathrm{X}_{3}-0.2150 \mathrm{X}_{2} \mathrm{X}_{3}-$ $5.69 X_{1}^{2}-2.77 X_{2}^{2}-1.80 X_{3}^{2}$

Color Removal $(\%)==+62.99+12.92 \mathrm{X}_{1}+11.64 \mathrm{X}_{2}+$ $13.57 \mathrm{X}_{3}+10.54 \mathrm{X}_{1} \mathrm{X}_{2}-0.2040 \mathrm{X}_{1} \mathrm{X}_{3}+1.29 \mathrm{X}_{2} \mathrm{X}_{3}-$ $13.74 \mathrm{X}_{1}^{2}-6.12 \mathrm{X}_{2}^{2}+3.95 \mathrm{X}_{3}^{2}$

This coded equation or that explained in terms of coded are needed to do the predictions about the response for given levels of each factor and comparing the factor coefficients for identifying the relative impact of the factors. Central composite Design from Design of Expert (11), analyzed the sequential model sum of squares and model summary statistics for different models such as linear, interactive, quadratic and cubic to get a good regression model. The expected results were indicated in Table 3, 4, 5 and 6 for the color removal using Al$\mathrm{Al}, \mathrm{Fe}-\mathrm{Fe}, \mathrm{Al}-\mathrm{Fe}$ and $\mathrm{Fe}-\mathrm{Al}$ electrode combination respectively. In Table 3, 5 and 6 the values of the coefficient of determination $\left(\mathrm{R}^{2}\right)$, Adjusted $\mathrm{R}^{2}$ and Predicted $\mathrm{R}^{2}$ were the highest in Quadratic model, but in Table 4, the two interaction model (2FI) exhibited the highest $\mathrm{R}^{2}$, adjusted $\mathrm{R}^{2}$ and predicted $\mathrm{R}^{2}$ compared to other models. On the other hand the cubic model is aliased, which indicates for further investigation the model is not appropriate and not enough experiments have been run to estimate independently in all terms of the model. According to the sequential model of squares indicated the P-values lower than 0.0022 for $\mathrm{Al}-\mathrm{Al}$ (Quadratic, two factorial interaction and linear models), 0.0105 for $\mathrm{Fe}-\mathrm{Fe}$ (Linear and two factorial interaction models), 0.0008 for Al-Fe (Quadratic and Linear models), and 0.0016 for Fe-Al (Quadratic and Linear models) could be for further investigation that shown in Table 3, 4, 5 and 6 respectively. Hence this indicates Quadratic models was chosen for further study and describe the effects operational parameters on the Application of Electrocoagulation for the removal of Color from Institutional wastewater.

\subsubsection{Adequacy of the model on Color Removal}

ANOVA (Analysis of Variance) was used to test the adequacy and the significance of the model. As shown in Table $7,8,9$ and 10 a very low $\mathrm{P}$-value $(<0.0001)$ was produced by the F-test of the regression models which indicating high significance of all models. On the other hand coefficient of determination $\left(\mathrm{R}^{2}\right)$ and Adjusted $\mathrm{R}^{2}$ were greater than $89 \%$ and $87 \%$ respectively as shown in Table 3, 4, 5 and 6 . This was a high significance of Color removal from institutional wastewater with the application of electrocoagulation. It was clearly observed that the percentage removal of color with the linear coefficients of $\mathrm{pH}\left(\mathrm{X}_{1}\right)$, Current $\left(\mathrm{X}_{2}\right)$ and Reaction time $\left(\mathrm{X}_{3}\right)$, interaction of $\mathrm{pH}\left(\mathrm{X}_{1}\right)$ with Current $\left(\mathrm{X}_{2}\right)$ and interaction of current $\left(\mathrm{X}_{2}\right)$ with reaction time $\left(\mathrm{X}_{3}\right)$ were the significant operational factors at $\mathrm{P}$-value less than 0.05 for $\mathrm{Al}-\mathrm{Al}$ and $\mathrm{Fe}$ $\mathrm{Fe}$, electrode combination that were shown in Table 7 and 8 respectively.

Table 2: Experimental design matrix by CCD and responses based on actual and predicted values on Color removal (\%) for different electrode combinations

\begin{tabular}{|c|c|c|c|c|c|c|c|c|c|c|c|}
\hline \multirow{2}{*}{ Run } & \multirow{2}{*}{$\begin{array}{l}\mathrm{X}_{1} \\
\mathrm{pH}\end{array}$} & \multirow{2}{*}{$\begin{array}{l}\mathrm{X}_{2} \\
\text { Current } \\
\text { (A) }\end{array}$} & \multirow{2}{*}{$\begin{array}{l}\mathrm{X}_{3} \\
\text { Reaction time } \\
\text { (minutes) }\end{array}$} & \multicolumn{2}{|c|}{$\begin{array}{l}\text { Color Removal (\%), } \\
\text { Al-Al }\end{array}$} & \multicolumn{2}{|c|}{$\begin{array}{l}\text { Color Removal (\%), } \\
\text { Fe-Fe }\end{array}$} & \multicolumn{2}{|c|}{$\begin{array}{l}\text { Color Removal (\%), } \\
\text { Al-Fe }\end{array}$} & \multicolumn{2}{|c|}{$\begin{array}{l}\text { Color Removal (\%), } \\
\text { Fe-Al }\end{array}$} \\
\hline & & & & Actual & Predicted & Actual & Predicted & Actual & Predicted & Actual & Predicted \\
\hline 1 & 3 & 0.03 & 20 & 23.10 & 22.32 & 33.10 & 34.99 & 48.48 & 47.52 & 23.81 & 20.57 \\
\hline 2 & 3 & 0.03 & 40 & 38.48 & 38.91 & 57.75 & 57.43 & 61.21 & 62.41 & 28.57 & 29.12 \\
\hline 3 & 3 & 0.03 & 60 & 61.54 & 61.89 & 78.87 & 77.30 & 73.94 & 73.71 & 42.86 & 45.55 \\
\hline 4 & 6 & 0.06 & 20 & 37.50 & 35.46 & 39.38 & 38.02 & 61.33 & 63.24 & 48.29 & 53.37 \\
\hline 5 & 6 & 0.06 & 40 & 50.00 & 50.20 & 62.00 & 61.94 & 81.33 & 78.53 & 65.00 & 62.99 \\
\hline 6 & 6 & 0.06 & 60 & 69.50 & 71.34 & 81.88 & 83.30 & 89.33 & 90.23 & 83.57 & 80.51 \\
\hline 7 & 9 & 0.09 & 20 & 62.50 & 62.65 & 43.50 & 46.36 & 70.15 & 69.92 & 71.10 & 67.52 \\
\hline 8 & 9 & 0.09 & 40 & 75.00 & 75.54 & 72.00 & 71.77 & 85.07 & 85.62 & 79.52 & 78.23 \\
\hline 9 & 9 & 0.09 & 60 & 95.50 & 94.82 & 97.24 & 94.62 & 98.03 & 97.71 & 91.95 & 96.82 \\
\hline 10 & 3 & 0.06 & 20 & 27.30 & 29.39 & 35.10 & 34.51 & 52.08 & 52.39 & 27.90 & 26.51 \\
\hline 11 & 3 & 0.06 & 40 & 45.20 & 44.37 & 58.00 & 59.15 & 67.00 & 67.07 & 34.00 & 36.34 \\
\hline 12 & 3 & 0.06 & 60 & 67.00 & 65.74 & 81.80 & 81.24 & 78.54 & 78.16 & 55.00 & 54.06 \\
\hline 13 & 6 & 0.09 & 20 & 42.25 & 42.64 & 41.90 & 39.65 & 66.78 & 66.51 & 54.32 & 57.60 \\
\hline 14 & 6 & 0.09 & 40 & 57.10 & 55.77 & 65.34 & 65.77 & 82.00 & 81.59 & 70.45 & 68.51 \\
\hline 15 & 6 & 0.09 & 60 & 74.34 & 75.29 & 87.52 & 89.34 & 92.40 & 93.08 & 88.64 & 87.31 \\
\hline 16 & 9 & 0.03 & 20 & 25.00 & 25.20 & 38.47 & 37.93 & 50.70 & 49.94 & 25.88 & 25.74 \\
\hline 17 & 9 & 0.03 & 40 & 40.30 & 41.30 & 59.90 & 58.93 & 64.67 & 66.07 & 31.50 & 33.87 \\
\hline 18 & 9 & 0.03 & 60 & 65.00 & 63.80 & 75.86 & 77.37 & 79.23 & 78.59 & 52.12 & 49.90 \\
\hline
\end{tabular}


Table 3: sequential model sum of squares and statistical model summary for Color Removal (\%) Using Al-Al

\begin{tabular}{|c|c|c|c|c|c|c|c|}
\hline \multicolumn{8}{|c|}{ Sequential Model Sum of Squares } \\
\hline Source & & $\begin{array}{l}\text { Sum } \\
\text { Squares }\end{array}$ & of $d$ & Mean Square & F-value & p-value & \\
\hline Mean vs Total & & 50839.04 & 1 & 50839.04 & & & \\
\hline Linear vs Mean & & 6163.67 & 3 & 2054.56 & 56.39 & $<0.0001$ & \\
\hline 2FI vs Linear & & 389.91 & 3 & 129.97 & 11.89 & 0.0009 & \\
\hline Quadratic vs 2FI & & 99.02 & 3 & 33.01 & 12.46 & 0.0022 & Suggested \\
\hline Cubic vs Quadratic & & 19.57 & 5 & 3.91 & 7.24 & 0.0670 & Aliased \\
\hline Residual & & 1.62 & 3 & 0.5405 & & & \\
\hline Total & & 57512.82 & 1 & 3195.16 & & & \\
\hline \multicolumn{8}{|c|}{ Model Summary Statistics } \\
\hline Source & Std. Dev. & & $\mathbf{R}^{2}$ & Adjusted $\mathbf{R}^{2}$ & Predicted $\mathbf{R}^{2}$ & PRESS & \\
\hline Linear & 6.04 & & 0.9236 & 0.9072 & 0.8649 & 901.30 & \\
\hline $2 \mathrm{FI}$ & 3.31 & & 0.9820 & 0.9722 & 0.9442 & 372.14 & \\
\hline Quadratic & 1.63 & & 0.9968 & 0.9933 & 0.9826 & 115.91 & Suggested \\
\hline Cubic & 0.7352 & & 0.9998 & 0.9986 & 0.9717 & 189.11 & Aliased \\
\hline
\end{tabular}

Table 4: sequential model sum of squares and statistical model summary for Color Removal (\%) Using Fe-Fe

\begin{tabular}{|c|c|c|c|c|c|c|}
\hline \multicolumn{7}{|c|}{ Sequential Model Sum of Squares } \\
\hline Source & $\begin{array}{l}\text { Sum } \\
\text { Squares }\end{array}$ & df & Mean Square & F-value & p-value & \\
\hline Mean vs Total & 68401.91 & 1 & 68401.91 & & & \\
\hline Linear vs Mean & 6551.44 & 3 & 2183.81 & 247.76 & $<0.0001$ & \\
\hline 2FI vs Linear & 77.20 & 3 & 25.73 & 6.13 & 0.0105 & Suggested \\
\hline Quadratic vs 2FI & 6.99 & 3 & 2.33 & 0.4754 & 0.7081 & \\
\hline Cubic vs Quadratic & 38.44 & 5 & 7.69 & 29.60 & 0.0093 & Aliased \\
\hline Residual & 0.7791 & 3 & 0.2597 & & & \\
\hline Total & 75076.75 & 18 & 4170.93 & & & \\
\hline \multicolumn{7}{|c|}{ Model Summary Statistics } \\
\hline Source & Std. Dev. & $\mathbf{R}^{2}$ & Adjusted $\mathbf{R}^{2}$ & ${\text { Predicted } \mathbf{R}^{2}}^{2}$ & PRESS & \\
\hline Linear & 2.97 & 0.9815 & 0.9776 & 0.9638 & 241.53 & \\
\hline $2 \mathrm{FI}$ & 2.05 & 0.9931 & 0.9893 & 0.9669 & 221.20 & Suggested \\
\hline Quadratic & 2.21 & 0.9941 & 0.9875 & 0.9564 & 290.69 & \\
\hline Cubic & 0.5096 & 0.9999 & 0.9993 & 0.9895 & 69.80 & Aliased \\
\hline
\end{tabular}

Table 5: sequential model sum of squares and statistical model summary for Color Removal (\%) Using Al-Fe

\begin{tabular}{|c|c|c|c|c|c|c|}
\hline \multicolumn{7}{|c|}{ Sequential Model Sum of Squares } \\
\hline Source & $\begin{array}{ll}\text { Sum } & \text { of } \\
\text { Squares } & \end{array}$ & df & Mean Square & F-value & p-value & \\
\hline Mean vs Total & 94217.06 & 1 & 94217.06 & & & \\
\hline Linear vs Mean & 3436.19 & 3 & 1145.40 & 102.98 & $<0.0001$ & \\
\hline 2FI vs Linear & 14.52 & 3 & 4.84 & 0.3769 & 0.7715 & \\
\hline Quadratic vs 2FI & 122.18 & 3 & 40.73 & 17.13 & 0.0008 & Suggested \\
\hline Cubic vs Quadratic & 4.40 & 5 & 0.8795 & 0.1804 & 0.9522 & Aliased \\
\hline Residual & 14.63 & 3 & 4.88 & & & \\
\hline Total & 97808.97 & 18 & 5433.83 & & & \\
\hline \multicolumn{7}{|c|}{ Model Summary Statistics } \\
\hline Source & Std. Dev. & $\mathbf{R}^{2}$ & Adjusted R ${ }^{2}$ & Predicted R ${ }^{2}$ & PRESS & \\
\hline Linear & 3.34 & 0.9566 & 0.9474 & 0.9396 & 216.95 & \\
\hline $2 \mathrm{FI}$ & 3.58 & 0.9607 & 0.9392 & 0.9267 & 263.45 & \\
\hline Quadratic & 1.54 & 0.9947 & 0.9887 & 0.9762 & 85.46 & Suggested \\
\hline Cubic & 2.21 & 0.9959 & 0.9769 & 0.8608 & 499.86 & Aliased \\
\hline
\end{tabular}


Table 6: sequential model sum of squares and statistical model summary for Color Removal (\%) Using Fe-Al

\begin{tabular}{|c|c|c|c|c|c|c|}
\hline \multicolumn{7}{|c|}{ Sequential Model Sum of Squares } \\
\hline Source & $\begin{array}{l}\text { Sum } \\
\text { Squares }\end{array}$ & of $\mathrm{df}$ & Mean Square & F-value & p-value & \\
\hline Mean vs Total & 52756.18 & 1 & 52756.18 & & & \\
\hline Linear vs Mean & 7998.53 & 3 & 2666.18 & 39.35 & $<0.0001$ & \\
\hline 2FI vs Linear & 140.06 & 3 & 46.69 & 0.6352 & 0.6077 & \\
\hline Quadratic vs $2 \mathrm{FI}$ & 677.92 & 3 & 225.97 & 13.84 & 0.0016 & Suggested \\
\hline Cubic vs Quadratic & 113.53 & 5 & 22.71 & 3.99 & 0.1420 & Aliased \\
\hline Residual & 17.07 & 3 & 5.69 & & & \\
\hline Total & 61703.30 & 18 & 3427.96 & & & \\
\hline \multicolumn{7}{|c|}{ Model Summary Statistics } \\
\hline Source & Std. Dev. & $\mathbf{R}^{2}$ & Adjusted R $\mathbf{R}^{2}$ & Predicted $\mathbf{R}^{2}$ & PRESS & \\
\hline Linear & 8.23 & 0.8940 & 0.8713 & 0.8406 & 1426.42 & \\
\hline $2 \mathrm{FI}$ & 8.57 & 0.9096 & 0.8603 & 0.8276 & 1542.35 & \\
\hline Quadratic & 4.04 & 0.9854 & 0.9690 & 0.9109 & 797.51 & Suggested \\
\hline Cubic & 2.39 & 0.9981 & 0.9892 & 0.8662 & 1197.18 & Aliased \\
\hline
\end{tabular}

Table 7: ANOVA for the adequacy of the model using Al-Al

\begin{tabular}{lllllll}
\hline Source & Sum of Squares & df & Mean Square & F-value & p-value & Remarks \\
\hline Model & 6652.59 & 9 & 739.18 & 279.11 & $<0.0001$ & Highly significant \\
$\mathrm{X}_{1}$-pH & 478.83 & 1 & 478.83 & 180.80 & $<0.0001$ & Highly significant \\
$\mathrm{X}_{2}$-Current & 527.91 & 1 & 527.91 & 199.33 & $<0.0001$ & Highly significant \\
$\mathrm{X}_{3}$ - Reaction Time & 3860.33 & 1 & 3860.33 & 1457.63 & $<0.0001$ & Highly significant \\
$\mathrm{X}_{1} \mathrm{X}_{2}$ & 269.35 & 1 & 269.35 & 101.71 & $<0.0001$ & Highly significant \\
$\mathrm{X}_{1} \mathrm{X}_{3}$ & 0.4332 & 1 & 0.4332 & 0.1636 & 0.6965 & \\
$\mathrm{X}_{2} \mathrm{X}_{3}$ & 19.41 & 1 & 19.41 & 7.33 & 0.0268 & significant \\
$\mathrm{X}_{1}{ }^{2}$ & 24.71 & 1 & 24.71 & 9.33 & 0.0157 & significant \\
$\mathrm{X}_{2}{ }^{2}$ & 37.46 & 1 & 37.46 & 14.14 & 0.0055 & significant \\
$\mathrm{X}_{3}{ }^{2}$ & 40.90 & 1 & 40.90 & 15.44 & 0.0044 & significant \\
Residual & 21.19 & 8 & 2.65 & & & \\
Cor Total & 6673.78 & 17 & & & & \\
\hline
\end{tabular}

Table 8: ANOVA for the adequacy of the model using Fe-Fe

\begin{tabular}{|c|c|c|c|c|c|c|}
\hline Source & Sum of Squares & df & Mean Square & F-value & p-value & Remarks \\
\hline Model & 6635.63 & 9 & 737.29 & 150.41 & $<0.0001$ & Highly significant \\
\hline $\mathrm{X}_{1-\mathrm{pH}}$ & 60.57 & 1 & 60.57 & 12.36 & 0.0079 & Significant \\
\hline $\mathrm{X}_{2}$-Current & 95.65 & 1 & 95.65 & 19.51 & 0.0022 & Significant \\
\hline $\mathrm{X}_{3}$ - Reaction Time & 6152.65 & 1 & 6152.65 & 1255.15 & $<0.0001$ & Highly Significant \\
\hline $\mathrm{X}_{1} \mathrm{X}_{2}$ & 26.47 & 1 & 26.47 & 5.40 & 0.0486 & Significant \\
\hline $\mathrm{X}_{1} \mathrm{X}_{3}$ & 3.87 & 1 & 3.87 & 0.7902 & 0.4000 & \\
\hline $\mathrm{X}_{2} \mathrm{X}_{3}$ & 36.45 & 1 & 36.45 & 7.44 & 0.0260 & Significant \\
\hline $\mathrm{X}_{1}^{2}$ & 0.3922 & 1 & 0.3922 & 0.0800 & 0.7845 & \\
\hline $\mathrm{X}_{2}{ }^{2}$ & 0.0654 & 1 & 0.0654 & 0.0133 & 0.9109 & \\
\hline $\mathrm{X}_{3}{ }^{2}$ & 6.55 & 1 & 6.55 & 1.34 & 0.2809 & \\
\hline Residual & 39.22 & 8 & 4.90 & & & \\
\hline Cor Total & 6674.84 & 17 & & & & \\
\hline
\end{tabular}


Table 9: ANOVA for the adequacy of the model using Al-Fe

\begin{tabular}{lllllll}
\hline Source & Sum of Squares & df & Mean Square & F-value & p-value & Remarks \\
\hline Model & 3572.88 & 9 & 396.99 & 166.93 & $<0.0001$ & Highly significant \\
$\mathrm{X}_{1}$-pH & 199.72 & 1 & 199.72 & 83.98 & $<0.0001$ & Highly significant \\
$\mathrm{X}_{2}$-Current & 204.21 & 1 & 204.21 & 85.87 & $<0.0001$ & Highly significant \\
$\mathrm{X}_{3}$ - Reaction Time & 2185.65 & 1 & 2185.65 & 919.07 & $<0.0001$ & Highly significant \\
$\mathrm{X}_{1} \mathrm{X}_{2}$ & 69.90 & 1 & 69.90 & 29.39 & 0.0006 & Significant \\
$\mathrm{X}_{1} \mathrm{X}_{3}$ & 2.84 & 1 & 2.84 & 1.19 & 0.3066 & \\
$\mathrm{X}_{2} \mathrm{X}_{3}$ & 0.3467 & 1 & 0.3467 & 0.1458 & 0.7125 & \\
$\mathrm{X}_{1}{ }^{2}$ & 83.17 & 1 & 83.17 & 34.97 & 0.0004 & Significant \\
$\mathrm{X}_{2}{ }^{2}$ & 19.74 & 1 & 19.74 & 8.30 & 0.0205 & Significant \\
$\mathrm{X}_{3}{ }^{2}$ & 12.92 & 1 & 12.92 & 5.43 & 0.0481 & Significant \\
Residual & 19.02 & 8 & 2.38 & & & \\
Cor Total & 3591.91 & 17 & & & & \\
\hline
\end{tabular}

Table 10: ANOVA for the adequacy of the model using Fe-Al

\begin{tabular}{lllllll}
\hline Source & Sum of Squares & df & Mean Square & F-value & p-value & \\
\hline Model & 8816.51 & 9 & 979.61 & 60.01 & $<0.0001$ & Highly significant \\
$\mathrm{X}_{1}$-pH & 1001.04 & 1 & 1001.04 & 61.32 & $<0.0001$ & Highly significant \\
$\mathrm{X}_{2}$-Current & 812.70 & 1 & 812.70 & 49.78 & 0.0001 & Highly significant \\
$\mathrm{X}_{3}$ - Reaction Time & 2209.74 & 1 & 2209.74 & 135.36 & $<0.0001$ & Highly significant \\
$\mathrm{X}_{1} \mathrm{X}_{2}$ & 499.91 & 1 & 499.91 & 30.62 & 0.0006 & Significant \\
$\mathrm{X}_{1} \mathrm{X}_{3}$ & 0.3121 & 1 & 0.3121 & 0.0191 & 0.8934 & \\
$\mathrm{X}_{2} \mathrm{X}_{3}$ & 12.40 & 1 & 12.40 & 0.7598 & 0.4088 & Significant \\
$\mathrm{X}_{1}{ }^{2}$ & 485.22 & 1 & 485.22 & 29.72 & 0.0006 & Significant \\
$\mathrm{X}_{2}{ }^{2}$ & 96.36 & 1 & 96.36 & 5.90 & 0.0412 & \\
$\mathrm{X}_{3}{ }^{2}$ & 62.30 & 1 & 62.30 & 3.82 & 0.0865 & \\
Residual & 130.60 & 8 & 16.33 & & & \\
Cor Total & 8947.11 & 17 & & & & \\
\hline
\end{tabular}

Also, the linear coefficients of $\mathrm{pH}\left(\mathrm{X}_{1}\right)$, Current $\left(\mathrm{X}_{2}\right)$ and Reaction time $\left(\mathrm{X}_{3}\right)$ and interaction of $\mathrm{pH}\left(\mathrm{X}_{1}\right)$ with Current $\left(\mathrm{X}_{2}\right)$ were the significant operational factors at $\mathrm{P}$-value less than 0.05 for $\mathrm{Al}-\mathrm{Fe}$ and $\mathrm{Fe}-\mathrm{Al}$ electrode combination that were shown in Table 9 and 10 respectively. Experiments (Actual) and Predicted values are shown in Table 2 for all electrode combinations and in addition to this, the relationship between Actual and predicted values are indicated in Fig. 2 (a), (b), (c) and (d). In this case all the data or points are closed or arranged towards the diagonal line which shows as the predicted data are matched to an actual (experimental values). Hence, for all electrode combinations the regression of Coefficient of Determination $\left(\mathrm{R}^{2}\right)$ for quadratic equation was a good fit for removal of color.

\subsubsection{Effects of combined operating parameters on Color Removal}

Different operating parameters are considered by central Composite Design from response surface Methodology such as $\mathrm{pH}$ with current, $\mathrm{pH}$ with reaction time and current with reaction time and their effects on the removal percentage of Color.

\subsubsection{Current with $\mathrm{pH}$}

During experimental study $\mathrm{pH}$ and electric current applied were operational factors that influence the removal percentage color using electrocoagulation process. As shown in Fig. 3 (a), (b), (c) and (d) the three dimensional response was observed on the removal of color. In all figures the removal percentage of color was increased as the $\mathrm{pH}$ increases from 3-9 and electric current increases from 0.03A-0.09A. In all electrode combination the highest removal percentage of color was observed when the solution was in basic condition. This was due to high concentration of hydroxide ions $\left(\mathrm{OH}^{-}\right)$formed because of water reduced at the cathode that related to the increasing of $\mathrm{pH}(47)$.

\subsubsection{Optimization}

The other crucial study part of this investigation is to get an optimum conditions on the removal percentage of color from institutional wastewater through the application of electrocoagulation by considering different operational factors and that was implemented Central Composite Design from Response Surface Methodology. During the optimization process operational factors such as $\mathrm{pH}\left(\mathrm{X}_{1}\right)$, Current $\left(\mathrm{X}_{2}\right)$ and Reaction time $\left(\mathrm{X}_{3}\right)$ were selected in a range and removal percentage of color was maximized. The optimum values were obtained for color removal (\%) using Al-Al, Fe-Fe, Al-Fe and $\mathrm{Fe}-\mathrm{Al}$ that was shown in Table 11. 


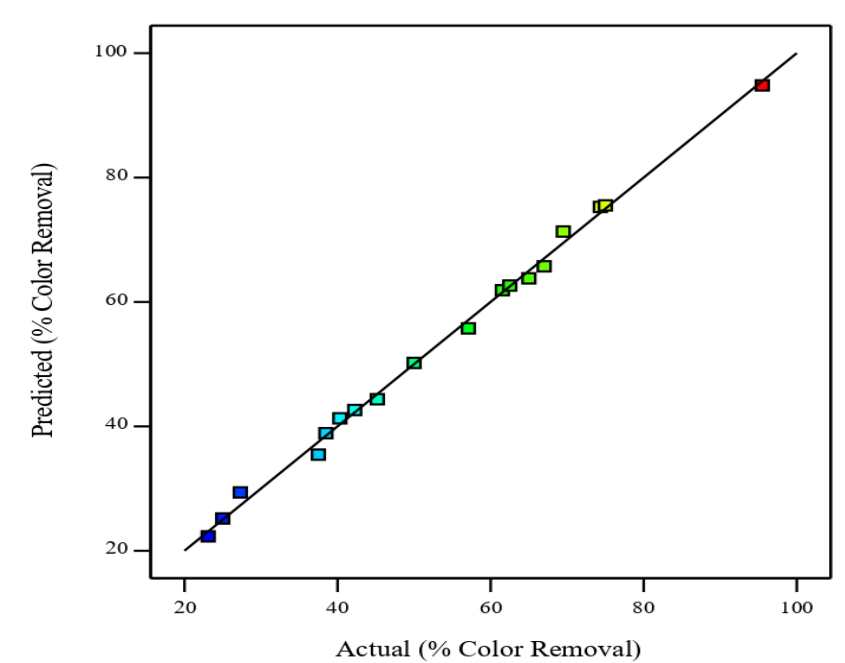

(a) Using $\mathrm{Al}-\mathrm{Al}$

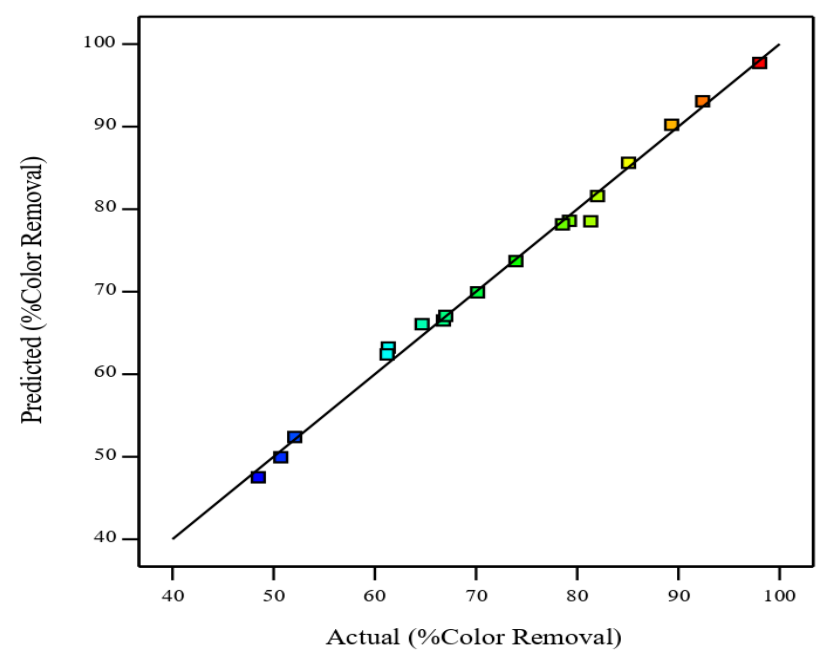

(c) Using $\mathrm{Al}-\mathrm{Fe}$

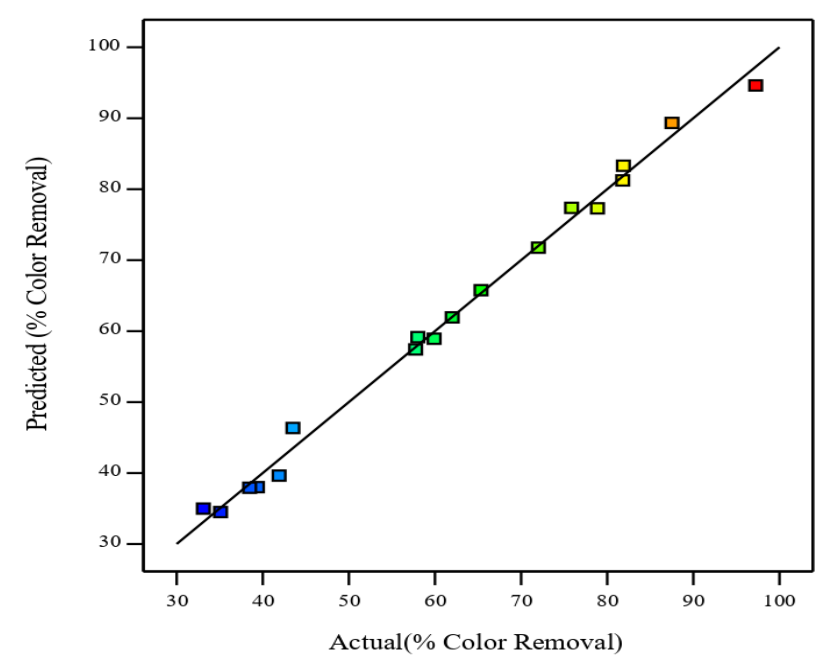

(b) Using Fe-Fe

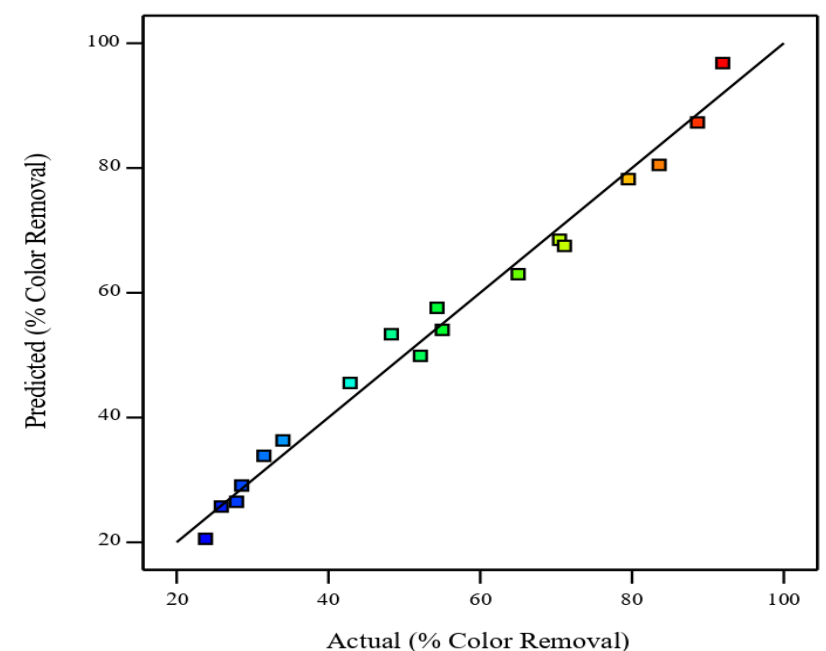

(d) Using $\mathrm{Fe}-\mathrm{Al}$

Figure 2: Relationship between Actual and Predicted values for \% of color removal using (a) Al-Al, (b) Fe-Fe, (c) Al-Fe and (d) Fe-Al

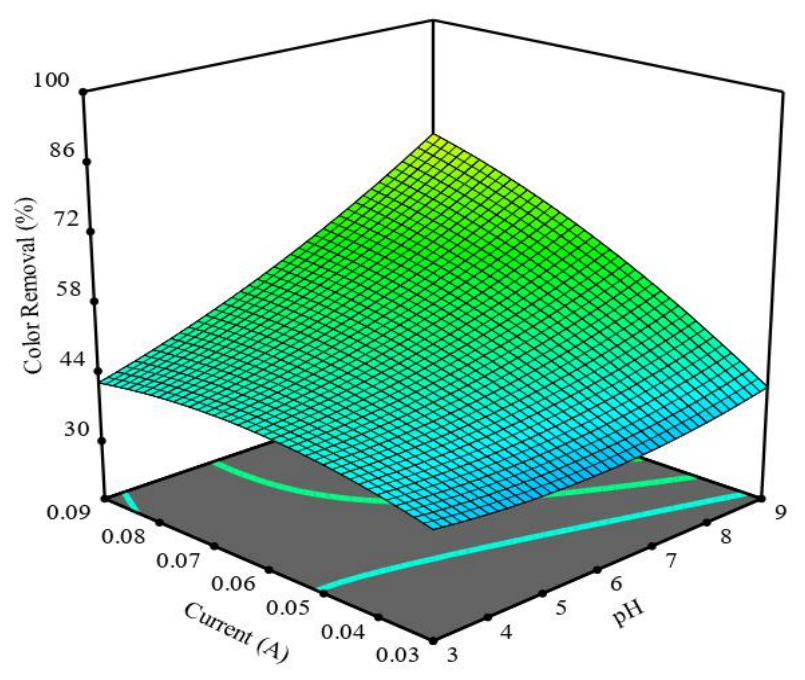

(a) Using $\mathrm{Al}-\mathrm{Al}$

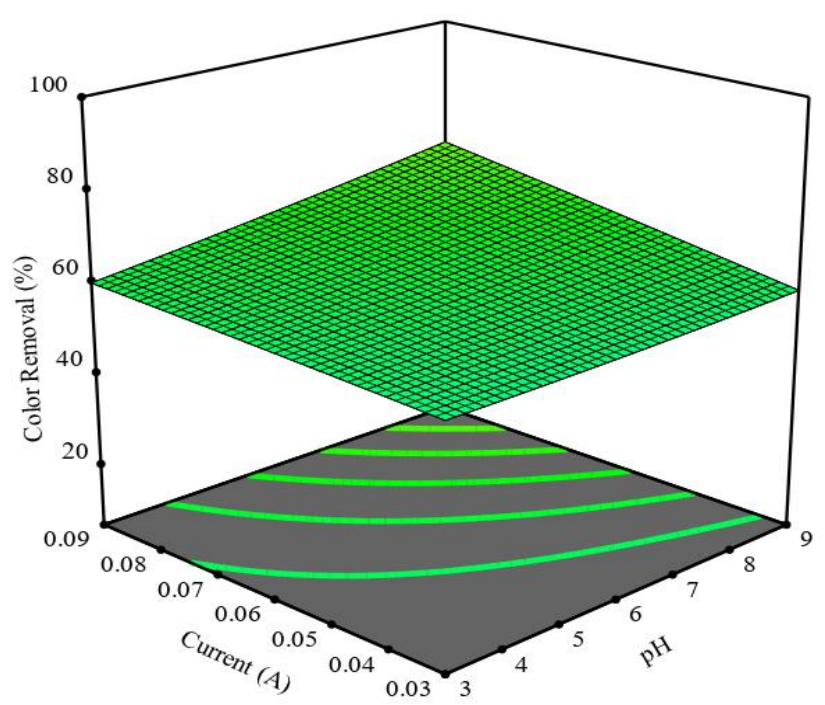

(b) Using $\mathrm{Fe}-\mathrm{Fe}$

Figure 3a: 3D surface plot on the interaction of current and $\mathrm{pH}$ for the removal of Color (a) Using Al-Al, (b) Using Fe-Fe, (c) Using Al-Fe and (d) Using Fe-Al 


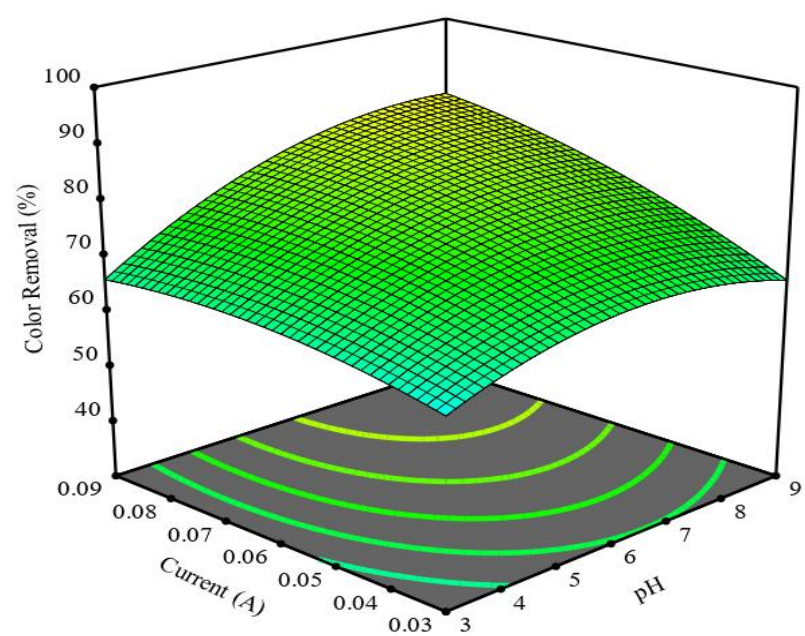

(c) Using Al-Fe

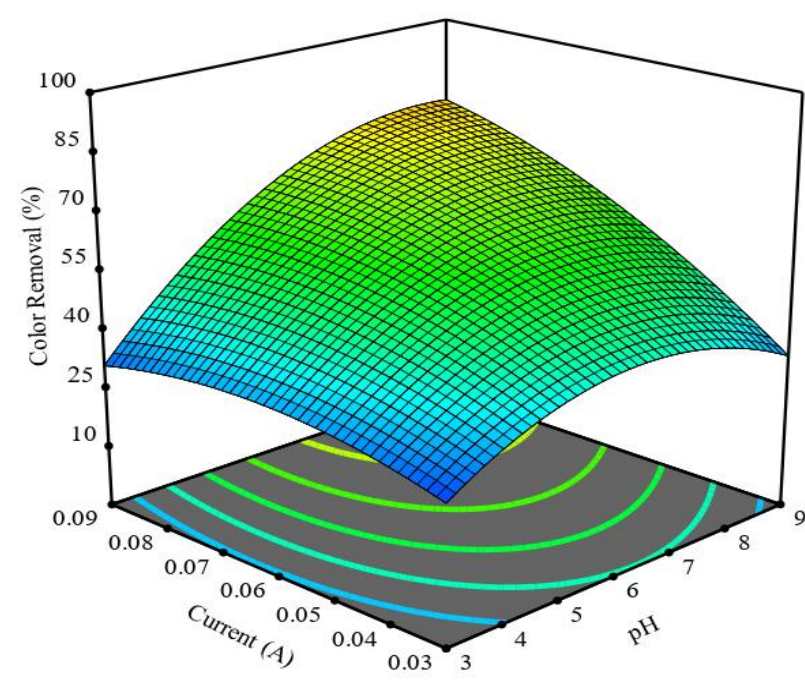

(d) Using $\mathrm{Fe}-\mathrm{Al}$

Figure 3b: 3D surface plot on the interaction of current and pH for the removal of Color (a) Using Al-Al, (b) Using Fe-Fe, (c) Using Al-Fe and (d) Using $\mathrm{Fe}-\mathrm{Al}$

Table 11: Optimum conditions for Color Removal (\%) using CCD design

\begin{tabular}{llllllll}
\hline Number & pH & Current & $\begin{array}{l}\text { Reaction } \\
\text { Time }\end{array}$ & $\begin{array}{l}\text { Color } \\
\text { Removal }\end{array}$ & Desirability & $\begin{array}{l}\text { Form of Electrode } \\
\text { Combination }\end{array}$ & Remark \\
\hline 1 & 9.000 & 0.090 & 60.000 & 94.819 & 0.991 & $\mathrm{Al}-\mathrm{Al}$ & Selected \\
2 & 9.000 & 0.090 & 60.000 & 94.616 & 0.959 & $\mathrm{Fe}-\mathrm{Fe}$ & selected \\
3 & 8.726 & 0.090 & 60.000 & 97.762 & 0.995 & $\mathrm{Al}-\mathrm{Fe}$ & Selected \\
4 & 7.980 & 0.083 & 57.916 & 92.203 & 1.000 & $\mathrm{Fe}-\mathrm{Al}$ & Selected \\
\hline
\end{tabular}

\section{Conclusion}

Electrocoagulation is a good technology used for the treatment of institutional wastewater like wastewater discharged from the higher educational center. Evaluation of decolorization from university wastewater studied by application of electrocoagulation by considering factors such as $\mathrm{pH}$, current and reaction time for an electrode combination of Aluminum and iron at the anode and cathode. Experimental results indicated color removal was somewhat an effective for all combinations of Aluminum and Iron within one hour reaction time. Statistical and mathematical data were analyzed by Central Composite Design. The significance of the model, operational factors and the interaction of each operational factor was made by CCD from RSM. In addition to this Central Composite Design was implemented that checked the validity and adequacy of the model as well as optimization was done for all electrode combinations.

\section{Ethical issue}

Authors are aware of, and comply with, best practice in publication ethics specifically with regard to authorship (avoidance of guest authorship), dual submission, manipulation of figures, competing interests and compliance with policies on research ethics. Authors adhere to publication requirements that submitted work is original and has not been published elsewhere in any language.

\section{Competing interests}

There is no conflict of interest.

\section{Authors' contribution}

I am a sole author of this paper and I have a contribution for data collection, data analyses and manuscript writing.

\section{References}

1. Marques RC, Miranda J. Sustainable tariffs for water and wastewater services. Util Policy. 2020;64.

2. Sirirerkratana K, Kemacheevakul P, Chuangchote S. Color removal from wastewater by photocatalytic process using titanium dioxide-coated glass, ceramic tile, and stainless steel sheets. J Clean Prod. 2019;215:123-30.

3. Amarine M, Lekhlif B, Sinan M, El Rharras A, Echaabi J. Treatment of nitrate-rich groundwater using electrocoagulation with aluminum anodes. Groundw Sustain Dev. 2020;11(September 2019):100371.

4. Khan NA, Khan SU, Ahmed S, Farooqi IH, Dhingra A, Hussain A, et al. Applications of nanotechnology in water and wastewater treatment: A review. Asian J Water, Environ Pollut. 2019;16(4):81-6.

5. Hakizimana JN, Gourich B, Chafi M, Stiriba Y, Vial C, Drogui P, et al. Electrocoagulation process in water treatment: A review of electrocoagulation modeling approaches. Desalination. 2017;404:1-21.

6. Manilal AM, Harinarayanan Nampoothiri MG, Soloman PA. Removal of oil and grease from automobile garage wastewater using electrocoagulation. IOP Conf Ser Mater Sci Eng. 2017;206(1):0-10.

7. Yehya T, Balla W, Chafi M, Audonnet F, Vial C, Essadki A, et al. Assessment of denitrification using electrocoagulation process. Can J Chem Eng. 2015;93(2):241-8.

8. Gurung A, Dahl O, Jansson K. The fundamental phenomena of nanobubbles and their behavior in wastewater treatment technologies. Geosystem Eng. 2016;19(3):133-42.

9. Nair DS, Sreedharan S. Reduction of Turbidity by Electrocoagulation. 2018;315-21.

10. Al-Qodah Z, Al-Shannag M. Heavy metal ions removal from wastewater using electrocoagulation processes: A comprehensive review. Sep Sci Technol. 2017;52(17):2649-76.

11. El-sayed MEA. Nanoadsorbents for water and wastewater remediation. Sci Total Environ. 2020;739:139903.

12. Nagarajappa D.P IJA. Domestic Wastewater Treatment by Electrocoagulation Using Copper and Aluminum Electrodes. Int J 
Innov Res Sci Eng Technol. 2015;04(06):3844-50.

13. Koyuncu S, Arıman S. Domestic wastewater treatment by realscale electrocoagulation process. Water Sci Technol. 2020;1-12.

14. Tripathi VK, Warwade P. Influence of Semi-arid Climate on Characterization of Domestic Wastewater. 2018;281-92.

15. Veli S, Arslan A, Bingöl D. Application of Response Surface Methodology to Electrocoagulation Treatment of Hospital Wastewater. Clean - Soil, Air, Water. 2016;44(11):1516-22.

16. Ince M, Ince OK. Application of response surface methodological approach to optimize removal of $\mathrm{Cr}$ ions from industrial wastewater. At Spectrosc. 2019;40(3):91-7.

17. Sharma S, Can OT, Hammed M, Nawarathna D, Simsek H. Organic pollutant removal from edible oil process wastewater using electrocoagulation. IOP Conf Ser Earth Environ Sci. 2018;142(1).

18. Azadi Aghdam M, Kariminia HR, Safari S. Removal of lignin, COD, and color from pulp and paper wastewater using electrocoagulation. Desalin Water Treat. 2016;57(21):9698-704.

19. Duan X, Wu P, Pi K, Zhang H, Liu D, Gerson AR. Application of modified electrocoagulation for efficient color removal from synthetic methylene blue wastewater. Int J Electrochem Sci. 2018;13(6):5575-88.

20. Fan $T$, Deng $W$, Feng $X$, Pan F, Li Y. An integrated electrocoagulation - Electrocatalysis water treatment process using stainless steel cathodes coated with ultrathin $\mathrm{TiO} 2$ nanofilms. Chemosphere. 2020;254:126776.

21. Hamada M, Ghalwa NA, B. Farhat N, Mahllawi K Al, Jamee N. Optimization of Electrocoagulation on Removal of Wastewater Pollutants. Int J Waste Resour. 2018;08(04):4-9.

22. Divyapriya G, Nambi IM, Senthilnathan J. Nanocatalysts in fenton based advanced oxidation process for water and wastewater treatment. J Bionanoscience. 2016;10(5):356-68.

23. Ozyonar F, Muratcobanoglu H, Gokkus O. Taguchi approach for color removal using electrocoagulation with different electrode connection types. Fresenius Environ Bull. 2017;26(12):7600-7.

24. Yusoff MS, Azwan AM, Zamri MFMA, Aziz HA. Removal of colour, turbidity, oil and grease for slaughterhouse wastewater using electrocoagulation method. AIP Conf Proc. 2017;1892.

25. Siddiqa A. Treatment of Service Station Wastewater Using. 2017;5:348-53.

26. Jung KW, Ahn KH. Dual purpose recovered coagulant from drinking water treatment residuals for adjustment of initial $\mathrm{pH}$ and coagulation aid in electrocoagulation process. Environ Technol (United Kingdom). 2016;37(13):1605-17.

27. Dehghani MH, Karimi B, Rajaei MS. The effect of aeration on advanced coagulation, flotation and advanced oxidation processes for color removal from wastewater. J Mol Liq. 2016;223:75-80.

28. Jaeel AJ, Ali NS. Color removal from textile wastewater using capparis spinosa as natural coagulant. Int Conf Adv Sustain Eng Appl ICASEA 2018 - Proc. 2018;165-8

29. Collivignarelli MC, Abbà A, Carnevale Miino M, Damiani S. Treatments for color removal from wastewater: State of the art. J Environ Manage. 2019;236(September 2018):727-45.

30. Jaeel AJ, Abdulkathum S. Sustainable pollutants removal from wastewater using sand filter: A review. Int Conf Adv Sustain Eng Appl ICASEA 2018 - Proc. 2018;179-83.

31. Salih Muharam SM, Rahmah CI, Yuningsih LM. Simultaneous Combination of Electrocoagulation and Chemical Coagulation Methods for Medical Wastewater Treatment. Makara J Sci. 2017;21(3):113-8.

32. Safwat SM. Treatment of real printing wastewater using electrocoagulation process with titanium and zinc electrodes. $\mathbf{J}$ Water Process Eng. 2020;34(September 2019):101137.

33. Papadopoulos KP, Economou CN, Tekerlekopoulou AG, Vayenas $D$ V. Two-step treatment of brewery wastewater using electrocoagulation and cyanobacteria-based cultivation. J Environ Manage. 2020;265(April):110543.

34. Benekos AK, Zampeta C, Argyriou R, Economou CN, Triantaphyllidou IE, Tatoulis TI, et al. Treatment of table olive processing wastewaters using electrocoagulation in laboratory and pilot-scale reactors. Process Saf Environ Prot. 2019;131:38-47.

35. Bouguerra W, Barhoumi A, Ibrahim N, Brahmi K, Aloui L, Hamrouni B. Optimization of the electrocoagulation process for the removal of lead from water using aluminium as electrode material. Desalin Water Treat. 2015;56(10):2672-81.
36. Mores R, Treichel H, Zakrzevski CA, Kunz A, Steffens J, Dallago RM. Remove of phosphorous and turbidity of swine wastewater using electrocoagulation under continuous flow. Sep Purif Technol. 2016;171:112-7.

37. Damaraju M, Bhattacharyya D, Kurilla KK. Removal of Recalcitrant Carbon from an Industrial Wastewater Using Electrocoagulation. Int J Civ Eng. 2017;15(4):697-703.

38. Kumar D, Sharma C. Reduction of chlorophenols and sludge management from paper industry wastewater using electrocoagulation process. Sep Sci Technol. 2019;0(0):1-11.

39. Perren W, Wojtasik A, Cai Q. Removal of Microbeads from Wastewater Using Electrocoagulation. ACS Omega 2018;3(3):3357-64.

40. Mohamud AA, Çalışkan Y, Bektaş N, Yatmaz HC. Investigation of shipyard wastewater treatment using electrocoagulation process with Al electrodes. Sep Sci Technol. 2018;53(15):2468-75.

41. Jo EY, Park SM, Yeo IS, Cha JD, Lee JY, Kim YH, et al. A study on the removal of sulfate and nitrate from the wet scrubber wastewater using electrocoagulation. Desalin Water Treat 2016;57(17):7833-40.

42. Khedher M, Mossad M, El-Etriby HK. Enhancement of Electrocoagulation Process for Dye Removal Using Powdered Residuals from Water Purification Plants (PRWPP). Water Air Soil Pollut. 2017;228(8)

43. Dehghani M, Seresht S, Hashemi H. Treatment of hospital wastewater by electrocoagulation using aluminum and iron electrodes. Int J Environ Health Eng. 2014;3(1):15.

44. GUO SB. Ournal of. Asian J Chem. 2014;26(12):70-3.

45. Butler E, Hung Y-T, Yeh RY-L, Suleiman Al Ahmad M Electrocoagulation in Wastewater Treatment. Water. 2011;3(2):495-525.

46. Yahiaoui I. Proceedings of the Third International Symposium on Materials and Sustainable Development. Proceedings of the Third International Symposium on Materials and Sustainable Development. Springer International Publishing; 2018. 527-539 p

47. Asaithambi P. Studies on various operating parameters for the removal of COD from pulp and paper industry using electrocoagulation process. Desalin Water Treat 2016;57(25):11746-55. 